\title{
A COLEÇÃO DE CARDÁPIOS DO INSTITUTO HISTÓRICO E GEOGRÁFICO BRASILEIRO: IMPRESSOS EFÊMEROS COMO FONTES PARA OS ESTUDOS SOBRE HISTÓRIA, POLÍTICA E SOCIABILIDADE
}

Lúcia Garcia

Universidade do Estado do Rio de Janeiro luciamcg1979@gmail.com

\section{Resumo:}

O presente artigo traz à luz documentos da cultura material que - por sua natureza - tantas vezes foram descartados e desvalorizados: a coleção de cardápios de almoços e jantares pertencentes ao Arquivo Histórico do Instituto Histórico e Geográfico Brasileiro. Datados da segunda metade do século XIX à primeira metade do século XX, esse conjunto de impressos efêmeros será tratado enquanto possibilidade metodológica e de pesquisa no campo da História Cultural, desvelando aspectos importantes da História, Política e Sociabilidade no Brasil.

Palavras-chave: História; Impressos Efêmeros; Cardápios.

\begin{abstract}
:
This article presents documents of material culture that has long been discarded and devalued: a collection of menus belonging to the Historical Archives of the Historical and Geographical Brazilian Institute. Dating from the second half of the nineteenth century to the first half of the twentieth century, this set of ephemeral prints will be treated as a methodological possibility and research in the field of Cultural History, revealing important aspects of the History, Politics and Sociability in Brazil.
\end{abstract}

Keywords: History; Ephemeral Prints; Menus. 
Os numerosos trabalhos acadêmicos sobre História Cultural que se têm realizado nos últimos anos são produto da revolução propiciada pela Escola dos Annales que resultou no paradigma historiográfico contemporâneo.

O historiador Lucien Febvre, um dos fundadores da referida corrente historiográfica, defendia a escolha de novos objetos de estudo no campo da História. Assim, a partir de 1950, muitos pesquisadores adotaram métodos e concepções diversos dos tradicionais para a realização do seu ofício, selecionando, para sua prática, temas inéditos em seu tempo, inserindo a História no campo intelectual da sociedade que a pensou. (NEVES,1984: p.17-39)

$\mathrm{Na}$ segunda metade do século $\mathrm{XX}$, ocasião que em proferiu a frase "A sensibilidade e a História: assunto novo. Não sei de livro onde seja tratado..." (FEBVRE, 1996: p.9), o autor talvez não imaginasse que seria levado tão a sério pelos historiadores. Felizmente, desde então, até os nossos dias, a sensibilidade e a História, com cada vez maior frequência, têm caminhado juntas.

É justamente nessa perspectiva teórica que o presente artigo traz à luz uma coleção de documentos da cultura material que - por sua natureza - tantas vezes foram descartados e desvalorizados: um conjunto de cardápios de almoços e jantares, datados da segunda metade do século XIX à primeira metade do século XX que, nesta oportunidade, serão tratados enquanto possibilidade metodológica e de pesquisa no campo da História Cultural.

O historiador Carlo Ginzburg nos aponta um caminho metodológico para o estudo da coleção de cardápios. Ao analisar o paradigma indiciário, modelo epistemológico surgido por volta do final do século XIX, Ginzburg defende o valor das pistas, dos indícios e dos pormenores para a explicação científica. Diz o autor que "é preciso procurar por detrás da realidade opaca, chaves de acesso privilegiadas que ajudem a decifrá-la”. (GINZBURG, 2003: p.177)

Os cardápios pertencentes ao Instituto Histórico, desse modo, são importantes chaves de acesso, que permitem não somente conhecer as redes de sociabilidade e as relações políticas estabelecidas entre a elite, do Império à República, como compreender os alimentos como símbolos de pertença social.

Para além do seu valor estético e gráfico, os cardápios constituem-se também como gênero textual e devem ser entendidos como artifícios de retórica, por conta de sua terminologia ornamental, do seu objetivo enunciativo e de um padrão sócio 
comunicativo característico, que integra elementos históricos, sociais, institucionais e técnicos.

Cabe ainda afirmar que os menus existentes na coleção do Instituto Histórico pertencem à categoria chamada, nos estudos de história gráfica, de impressos efêmeros. Desde 1962, o termo vem sendo regularmente empregado, ocasião em que John Lewis publicou o livro Printed Ephemera.

Segundo afirma o escritor e historiador da arte Rafael Cardoso:

A abrangência exata dessa alcunha é aberta a interpretação e discussões. No sentido mais amplo, são efêmeros todos os impressos produzidos com a intenção do descarte rápido - ou seja, tudo menos os livros. Assim, a rigor, jornais e revistas também poderiam ser concebidos como impressos efêmeros, pois são planejados para ter vida útil de um dia, uma semana, um mês. No sentido estrito, porém, costuma-se reservar o termo para designar os materiais ligados à vida cotidiana que não seriam preservados pela lógica tradicional das bibliotecas, por não se enquadrarem no conceito usual de volume (revistas e jornais constituem séries que, encadernadas, viram volumes). Alguns exemplos talvez ajudem a elucidar melhor a questão: cartazes, folhetos, prospectos, programas, anúncios, ingressos e bilhetes, cartões de visita, ex-libris, notas e apólices, diplomas, rótulos, embalagens e... cardápios.

Trata-se de uma aglomeração de materiais muito diferentes entre si, mas, que têm em comum sua inserção corriqueira na vida cotidiana e, em especial, nas atividades comerciais, representando ainda por vezes, status político e social. Geralmente produzidos para atender a finalidades imediatas e transitórias, os efêmeros refletem costumes de uma época com uma vivacidade e uma informalidade impensadas, que faltam, muitas vezes, às fontes impressas mais consideradas.

O efêmero, como se vê, é uma noção que faz mais sentido para o historiador do que para o usuário. O ímpeto principal para consolidar essa categoria tem partido dos formadores de coleções, tanto instituições quanto indivíduos. Com o advento da indústria gráfica no século XIX e a subsequente proliferação de impressos de todas as espécies, o mundo foi inundado de efêmeros - e, contrariando sua própria designação, os efêmeros subsistem. (CARDOSO, 2009: p 1112)

Rafael Cardoso destaca que, uma das primeiras coleções importantes a consolidar-se em nível internacional foi a John Johnson of Printed Ephemera, da Universidade de Oxford. Merecem destaque também as organizações privadas internacionais dedicadas ao tema, como a The Ephemera Society, de Londres, e The 
Ephemera Society of America, no estado de Nova York. A partir delas outras instituições passaram a dar atenção aos efêmeros, normalmente obliterados pelos acervos pela ausência de uma catalogação específica.

No Brasil, os efêmeros durante muito tempo não receberam a merecida atenção por parte de historiadores, arquivistas e bibliotecários e, sem a prática sistemática da sua catalogação em nossas instituições, muitos acervos permaneceram (e permanecem) frequentemente subestimados ou até desconhecidos. Contudo, sem a intenção de esgotar o assunto, destacamos nessa oportunidade algumas publicações que provam a mudança desse cenário.

No ano de 2009, foram lançados os livros "Impresso no Brasil: destaques da história gráfica no acervo da Biblioteca Nacional" (CARDOSO, 2009) e "Marcas do Progresso: consumo e design no Brasil do século XIX” (HEYNEMAMM, 2009), ambos da autoria do historiador da Arte Rafael Cardoso sendo esse último em coautoria com Claudia Beatriz Heynemann e Maria do Carmo Teixeira Rainho. As obras apresentam, respectivamente, parte do acervo de impressos efêmeros da Biblioteca Nacional do Rio de Janeiro e, o conjunto de embalagens e rótulos litográficos que compõem seis antigos livros de registro de marcas, oriundos da Junta Comercial do Rio de Janeiro.

Como desdobramento desse esforço de pesquisa realizado na Biblioteca Nacional, cabe destacar que, atualmente, em seus instrumentos de consulta e busca, a instituição já classifica como "Efêmeros" as cerca de mil peças - entre rótulos, diplomas, embalagens, folhetos... - que estão sob a guarda da Seção de Iconografia.

Mais recentemente, há cinco anos, a Imprensa Oficial do Estado de São Paulo, em coedição com a Academia Brasileira de Letras, editou a obra "Para uma história da belle époque: a coleção de cardápios de Olavo Bilac" (GARCIA, 2011), revelando parte do acervo inédito de impressos efêmeros do Arquivo Histórico da ABL, reunido pelo poeta Olavo Bilac, sócio fundador da Academia. Foi o primeiro livro que tomou de empréstimo informações contidas em menus para apresentar a trajetória biográfica de Bilac e suas redes de sociabilidade. Oferecendo elementos importantes para uma melhor compreensão da cultura política do Rio de Janeiro no início do século XX, cada banquete representava a pretensão do refinamento da elite, que preservava seu status também por meio dessas confraternizações sociais, celebrando certo gosto: aquele praticado pelas elites francesas.

Apresentado por Serge Bernstein (BERNSTEIN,1998: pp.349-363) o conceito de cultura política é de grande valia para o estudo da História através dos impressos 
efêmeros. Noção complexa, tal conceito pode ser entendido como um conjunto de ideias, referências, crenças e valores que entrelaçam o grupo social, sob pressupostos políticos. A cultura política está, portanto, inscrita no quadro das normas e dos valores que determinam a representação que uma sociedade faz de si mesma e de sua História. Por meio dessa chave é possível identificar as motivações que levam os grupos sociais a adotarem determinado comportamento ou defender certo conjunto de ideias a partir do sistema de valores, normas, crenças e representações que partilham.

Retomando as publicações cujos autores debruçaram-se sobre os impressos efêmeros, em 2013, mais uma contribuição. Naquele ano foi lançado o livro "Os banquetes do Imperador: menus colecionados por D. Pedro II. Receitas e historiografia da gastronomia no Brasil do século XIX”. (BOCCATO: LELLIS, 2013) Os Chefs de Cuisine - Francisco Lellis e André Boccato - debruçaram-se sobre o conjunto de cardápios que compõem a Coleção Thereza Christina, da Biblioteca Nacional. Não obstante o lamentável furto das principais peças que constituíam a coleção, episódio que antecedeu a referida pesquisa, os autores analisaram para mais de uma centena de menus, apresentando as receitas mais citadas na coleção e a Gastronomia brasileira no século XIX. Como desdobramento da pesquisa um dia realizada na Academia Brasileira de Letras, sobre os cardápios reunidos pelo poeta Olavo Bilac, iniciamos uma investigação sobre a coleção de menus do Instituto Histórico e Geográfico Brasileiro nunca antes estudada em seu conjunto e inédita em livro. ${ }^{1}$

Os pouco mais de 170 cardápios até o momento identificados são provenientes de diversas coleções. Há peças que pertenceram à Baronesa de Loreto (companheira de infância da Princesa Isabel que acompanhou a Família Imperial ao exílio), ao Senador Nabuco de Araújo (um dos artífices da Lei do Ventre Livre), a Afonso Celso de Assis Figueiredo (Visconde de Ouro Preto que presidiu ao último Conselho de Ministros do Império, acompanhando a Família Imperial ao exílio); ao Barão de Araújo Góis (Deputado Provincial no Império e Chefe da Polícia na Província da Bahia), a Araújo Pinho (Presidente da Província de Sergipe, Deputado geral pela Bahia e Senador estadual, genro do Barão de Cotegipe), a Manuel Luís Osório (Marquês de Herval, general que participara dos principais eventos militares do final do século

\footnotetext{
${ }^{1}$ Oportunamente publicaremos - também em livro - os resultados da pesquisa, hoje em desenvolvimento, como parte das comemorações pelos 180 anos do Instituto Histórico e Geográfico Brasileiro, a celebrar-se no ano de 2018.
} 
XIX), a Domício da Gama (Diplomata, escritor e membro fundador da Academia Brasileira de Letras), a Max Fleuiss (diretor da revista A Semana), ao arquiteto Paulo de Frontin, a Carlos César de Oliveira Sampaio (Prefeito do Distrito Federal), a José Carlos de Macedo Soares (Ministro da Justiça e dos Negócios Interiores de Getúlio Vargas), ao historiador Hélio Viana e a Victorino Chermont de Miranda, atual VicePresidente do IHGB. Merecem destaque, igualmente, inúmeros cardápios oriundos da Coleção Instituto Histórico, constituída por documentos de diversas procedências adquiridos por doações, aquisições ou através de missões enviadas ao estrangeiro pelo Imperador D. Pedro II.

O historiador europeu e Chef de Cuisine Tim Wätzold encantou-se pela cozinha brasileira. Tamanho interesse rendeu-lhe uma tese de doutorado defendida em 2011 na Universidade de Colônia, Alemanha. O texto, traduzido sob o título "Proclamação da cozinha brasileira como parte do processo de formação da identidade nacional no Império Brasileiro (1822-1889)", foi publicado em Belo Horizonte no ano de 2012.

No capítulo dedicado às recepções festivas o autor afirma:

O desenvolvimento da cozinha da alta sociedade brasileira se mostrou principalmente no âmbito das recepções festivas. Estas serviam como oportunidade para demonstrar prestígio à mesa. Em particular a elite do Rio de Janeiro encenava em tais momentos. Para essas ocasiões, os menus eram preparados de forma artística, nos quais a sequência de pratos e as bebidas correspondentes eram especificados. (W ̈̈TZOLD, 2012: p. 195)

Do Império à República, qualquer motivo de celebração era um bom pretexto para se oferecer um banquete. Porém, considerando que a quase totalidade dos menus que compõem o acervo do Instituto Histórico e Geográfico Brasileiro pertenceram a personagens centrais da História política brasileira, a coleção se faz ainda mais significativa, uma vez que muitos almoços e jantares constituíam-se como verdadeiros cerimoniais de Estado. É o que prova, por exemplo, o cardápio do banquete para solenizar a inauguração oficial dos serviços no novo porto da Bahia, a 13 de maio de 1913.

No jantar, oferecido pelo Governo do Estado da Bahia, muitas iguarias aqui se apresenta traduzidas do original francês: Creme São Germano (sopa de ervilhas), filé de peixe ao molho holandês (apesar do nome é um dos grandes trunfos da culinária francesa feito à base de gema de ovos, manteiga e suco de limão), maionese de 
camarões frescos, pato com romã ao molho brasileiro, peru recheado à moda baiana, presunto frio à maneira de York e panachê de legumes. De sobremesa, tortas de creme, de frutas e de gelatina, bolos variados da Bahia e frutas da estação. Finalmente, licores, café e charutos. O serviço do jantar foi fornecido pelo prestigiado Hotel Sul Americano, localizado à Praça Castro Alves, em Salvador.

O cardápio impresso, com decoração em alto relevo, sem referência à casa litográfica, possui detalhes interessantes do ponto de vista gráfico. Além de apresentar diferentes tipologias, traz um erro ortográfico e de impressão: nas sobremesas figura a palavra tartres e não tartes, do francês. Verifica-se outro aspecto curioso: o texto do cardápio que indica o local, a data e o motivo do banquete foi escrito em português e, como era tradição à época, a relação de iguarias, em francês.

Nota-se ainda uma distinção desse menu, datado de 1913, em relação a outros exemplares do século XIX: se antes a influência europeia na gastronomia brasileira era predominante, nesse cardápio atesta-se os frutos de um longo processo de mestiçagem. Vê-se, portanto, a referência à culinária baiana (bolos variados da Bahia) e, a presença de elementos da nossa cultura (pato com romã ao molho brasileiro). Assim, esses impressos efêmeros, individualmente e em seu conjunto, revelam também - para além de outros aspectos - o nascimento da tradição gastronômica brasileira.

Esse cardápio é acompanhado de um documento original jamais visto em coleções de efêmeros de outras instituições de pesquisa no Rio de Janeiro. Trata-se do mapa de lugares para o referido banquete, atestando a antecedência e o esforço logístico para a organização da luxuosa recepção.

O documento traz não somente a localização do assento e a indicação das seis grandes mesas que deveriam compor o salão, como também, o nome ou a indicação do cargo de todos os 306 convidados: Presidente do Senado, representantes do governo do Estado da Bahia, além naturalmente do anfitrião o Governador do Estado da Bahia Dr. José Joaquim Seabra, membros do governo municipal, muitos Senadores, Deputados, Militares, representantes dos principais jornais da época, de diversas Embaixadas e figuras da elite intelectual daquele tempo. Estaria presente, naturalmente, o corpo de Engenheiros responsável pelas obras. Atente-se para o valor simbólico desse documento: a escolha da posição à mesa de cada um dos convivas tinha, certamente, uma intenção. Afinal, era também à mesa que se praticava a arte da política e do conchavo. 
Imagine-se a importância da celebração. Naquele tempo a Bahia era o maior exportador de cacau em escala mundial e, ademais, tratava-se de banquete para solenizar a inauguração oficial dos serviços do novo Porto da Bahia.

Vale dizer que, durante o período colonial, o Porto de Salvador era comumente denominado "Porto do Brasil", como se fosse o único ancoradouro de toda a América Portuguesa. A referência traduzia, portanto, o significado histórico e econômico daquele porto para a Metrópole e, por conseguinte, justificava o fausto da celebração daquela noite.

A 13 de maio de 1913, inaugurava-se, então, o primeiro trecho do Cais da Alfândega, em solenidade presidida pelo governador Joaquim Seabra. A primeira embarcação a atracar no novo cais foi o paquete "Ilhéus", da Companhia de Navegação Baiana. Imediatamente, foi iniciada a exploração comercial do Porto de Salvador.

Constatando que representantes dos principais jornais da Bahia foram convidados para o referido banquete, buscamos nas páginas da Gazeta de Notícias, editado em Salvador, eventuais informações a respeito. E, em mais de um número do periódico, ocupando diversas páginas, lá estavam notícias das celebrações por ocasião da inauguração das obras do novo Porto da Bahia.

O jornal cobriu a solenidade de abertura no Armazém 2 na manhã do dia 13 de maio - com a transcrição na íntegra dos discursos proferidos pelas autoridades -, a descrição de momentos do baile promovido pela Associação Comercial na noite do dia 14 de maio e, sob a manchete "Grande Banquete oferecido pelo Governo do Estado às altas classes da Bahia, no Polytheama, para solenizar a inauguração oficial dos serviços do novo porto" o jantar oferecido no dia 13 de maio com riqueza de detalhes.

Acompanhando a matéria, na mesma página do periódico, temos a reprodução na íntegra, em grande formato, do mapa de lugares da recepção, cujo original está conservado no Instituto Histórico e Geográfico Brasileiro, documento a que nos referimos anteriormente. Mais uma vez se reforça a intenção política do banquete, cuja relação de convivas e seu mapeamento estratégico no salão serviu não somente à propaganda do governo do Estado da Bahia, mas também como vitrine das relações de sociabilidade que na época se estabeleciam, destacando o status social dos ali presentes.

Vejamos o que diz o jornal: 
Solenizando o grande acontecimento de ontem, da inauguração oficial de um extenso trecho de cais novo do nosso porto, fato esse que é de suma importância e de extraordinário relevo, na história da nossa evolução, o ilustra e honrado sr. Dr. José Joaquim Seabra, benemérito governador do Estado, ofereceu, no Polytheama Baiano, às altas classes sociais da nossa terra, um suntuoso banquete, no qual tomaram parte trezentos convivas.

Não se pode fazer uma ideia exata do que foi tão expressiva quanto imponente festa, sem que se tivesse admirado, de perto, o esplendor em que nadava fantasticamente iluminado e florido o amplo e cômodo salão da plateia do nosso antigo teatro, hoje muito melhorado nas suas condições internas.

(...) No palco, transformado em bosque e também iluminado por inúmeras lâmpadas elétricas tocava uma bem organizada orquestra (...), ficando instalada nas galerias uma banda de música policial(...).

Desde 7 e meia horas começaram a chegar os convidados (...).

Às 9 horas menos um quarto achavam-se todas as mesas ocupadas. (GAZETA DE NOTÍCIAS, 1858: p.3)

O redator apresenta as iguarias servidas, bem como o repertório executado pela orquestra, onde figuraram composições de Verdi e Puccini, bem como o Hino Nacional brasileiro e o Hino da República.

Vale mencionar que a reportagem não dispensou a menção ao tradicional “Discurso de Sobremesa”, proferido pelo anfitrião, que saudou os convivas por aquele auspicioso acontecimento, destacando que:

\begin{abstract}
(...) quisera ver neste momento solene reunido neste augusto recinto em que se festeja uma das maiores datas nacionais (...) todo o povo da Bahia. E se não o vejo na efetividade numérica, vejo-o, entretanto representado no que ele tem de mais ilustre e laborioso, nos dignos representantes de suas classes conservadoras e liberais, do seu comércio e da sua indústria, das briosas classes armadas, do seu funcionalismo, dos representantes dos altos poderes públicos do Estado (...) O ilustre sr. Governador, terminando a festa levantou o brinde de honra (...) e o Hino Nacional vibrou. Estava acabado o banquete. Eram 11 horas da noite”. (GAZETA DE NOTÍCIAS, 1858: p. 3)
\end{abstract}

A breve contextualização aqui realizada, a partir de um único exemplar de cardápio da sob a guarda do Arquivo do Instituto Histórico e Geográfico Brasileiro, favorece o entendimento de aspectos políticos, sociais e culturais de uma época e, nessa 
perspectiva, pretendemos ampliar o estudo, seja individualmente e/ou em conjunto, dos demais documentos identificados naquela mesma coleção.

Com recepção requintada - além do variado menu elaborado nos moldes da elegante gastronomia francesa, delicadas porcelanas, pratarias e cristais - os banquetes oferecidos aos membros da elite intelectual e política brasileira, na transição do século XIX para o XX, celebravam desde efemérides da História pátria à conclusão de obras públicas ou de equipamentos urbanos, homenageavam um escritor, artista ou político, comemoravam seu natalício, marcavam a despedida de um intelectual que partia em viagem ou a alegria do seu regresso...

Diante do fausto dessas recepções, não é difícil relegar às motivações dos banquetes importância secundária. O espírito era o de celebração regada à boa comida, com atenção aos rituais que envolviam a recepção e a etiqueta à mesa.

A coleção guarda cardápios de almoços e jantares oferecidos em homenagem a figuras ilustres do cenário político e intelectual - no Império e na República - ou, apresenta exemplares que marcam a ampliação da rede férrea do Brasil, como o menu impresso de $1^{\circ}$ de abril de 1909 que celebra a inauguração dos novos trechos da linha de Itararé e ligação com a estrada de ferro São Paulo-Rio Grande. Outras vezes, a reunião de convivas regadas à boa gastronomia se dava por ocasião da recepção de uma figura ilustre em terras estrangeiras, a exemplo do cardápio de banquete oferecido ao Barão do Rio Branco, por amigos brasileiros, na ocasião de sua chegada em Londres, em 15 de dezembro de 1900. Ou, ao contrário, por ocasião de uma despedida, como prova o menu do jantar em homenagem ao escritor Valentim Magalhães, em 23 de julho de 1894. São muitos os almoços e jantares oferecidos a figuras de relevo, até mesmo sem qualquer ocasião especial para justificá-los, a não ser a cultura política da época que exigia a manutenção de laços de sociabilidade, como garantia de cargos e determinadas vantagens políticas.

Nos menus do Instituto Histórico e Geográfico Brasileiro estão também presentes as tradicionais Confeitarias Pascoal, Cailtau, Ouvidor e Colombo, do Rio de Janeiro - oferecendo seus tradicionais serviços nas recepções de gala em casas de particulares ou salões -, entre outros estabelecimentos comerciais do início do século XX no Brasil ou no estrangeiro. 
Também compõe a coleção do IHGB o famoso cardápio da festa oferecida à oficialidade do encouraçado chileno Almirante Cochrane, em 1889, o "Baile na Ilha Fiscal" e, graciosos menus de recepções oferecidas pela Condessa de Barral em Petrópolis, pelo Barão de Massambará em Vassouras ou, pela Princesa de Joinville em Paris.

Merece destaque na coleção o conjunto cardápios do jantar oferecido em 1920 aos Reis dos Belgas, pelo Prefeito do Distrito Federal, Carlos Sampaio. Acondicionados em uma caixa estão em perfeito estado belíssimos 26 exemplares com litografias de paisagens do Rio de Janeiro, mais especificamente da Floresta da Tijuca, emolduradas por ornamentações variadas em aquarela. Cada primorosa peça, em francês, parte dela impressa e parte dela manuscrita, traz amarração lateral com finíssimas fitas em cetim nas cores amarelo, preto e vermelho - em referência à Bélgica -, além de um pequenino cartão que, pendurado no menu através de um fino cordão de seda, indica o nome de cada um dos convidados.

Assim como o cardápio da inauguração das obras do novo Porto da Bahia não traz indicação da casa litográfica, o menu do jantar oferecido aos Reis dos Belgas, não fornece qualquer informação a esse respeito.

Cabe destacar, contudo, que muitos cardápios impressos, presentes à coleção, trazem à margem o nome de até duas tipografias em um mesmo exemplar. Isso porque, certas vezes, a matriz da peça gráfica era impressa no exterior e, sendo adquirida em branco, seria realizada no Brasil a impressão do texto sob a chancela de uma casa tipográfica local, a exemplo de muitos menus impressos no Rio de Janeiro pela Casa Leuzinger.

Nas circunstâncias em que eram adquiridas as matrizes de cardápios das casas tipográficas - sobretudo no caso de restaurantes, hotéis e navios - o impresso originalmente "em branco" era manuscrito por um amanuese, dada a rotatividade das refeições. Não raro encontramos menus de navios manuscritos, com datas e listas de iguarias distintas e aparência gráfica semelhante, naquilo que lhe foi impresso.

A coleção do IHGB, entre outros exemplares de extraordinário valor, possui menus em seda e outros tantos confeccionados em papéis de diferentes tons, qualidades, formatos e gramaturas. Entre as jóias gráficas que merecem destaque, vale mencionar o exemplar - com amarração em fio de seda -, do banquete em honra ao Marechal Hermes da Fonseca, oferecido pela Associação Comercial da Bahia, em 18 de julho de 1911. No interior do impresso, à esquerda, figura um retrato do Marechal, 
gravura cujo desenho é assinado por Modesto Brocos, pintor, desenhista e gravador espanhol radicado no Brasil a partir de 1890, autor de telas conhecidas como "A Redenção de Cam”, que aborda as teorias raciais do fim do século XIX. Esse excepcional exemplar possui ainda outro aspecto a destacar: as iguarias são apresentadas em português, algo pouco usual considerando-se o padrão da época. Interessante notar que, na relação de pratos, alguns fazem alusão ao homenageado (Garoupa à Marechal), à Bahia (Ponche à Bahiana), à Associação Comercial que oferecia o banquete (Salada à Associação Comercial) e, ainda, ao Conde dos Arcos (Peru a Conde dos Arcos), Marcos de Noronha e Brito, uma referência ao administrador colonial português que, por ocasião da chegada do Príncipe Regente D. João, em Salvador, em janeiro de 1808, foi nomeado Governador da Bahia.

Em francês ou em português, finamente decorados, o que se comprova por meio dos cardápios é que membros da elite, no Império ou na República, estavam acostumados a uma rotina de almoços, jantares e banquetes, cuja presença garantia a manutenção das relações sociais e do prestígio pessoal, necessário para o bom trânsito político nas instituições que desejavam frequentar, manter influência ou obter privilégios. Verifica-se também a prática do colecionismo, comum entre os homens cultos da segunda metade do século XIX e da primeira metade do século XX, que reuniam cardápios para eternizar um momento memorável.

A propósito, é bem provável que durante muito tempo tenham colecionado menus. Afinal, cardápio constitui-se em neologismo criado 1889 pelo filólogo Antônio de Castro Lopes (1827-1901) para substituir a palavra menu em francês.

$\mathrm{Na} 2^{\mathrm{a}}$ edição do livro Neologismos indispensáveis datada de 1909, ao tratar da palavra francesa menu, Castro Lopes afirma, à semelhança do que publicou originalmente no Jornal Gazeta de Notícias em 23 de março de 1889:

Nobres e plebeus, ricos e pobres, sabem que nos suntuosos banquetes, ou nas casas de pasto de alta ou de medíocre categoria, chama-se afrancesadamente Menu a lista das viandas, das iguarias, enfim, o rol dos manjares.

Desculpam-se do barbarismo todos os que o empregam, por não existir em português palavra que exprima o que Menu francês significa.

Mas a verdadeira e genuína significação de Menu é miúdo, e essa palavra foi por convenção admitida para substituir esta ou outra frase semelhante: almoço, jantar ou ceia, descritos pelo miúdo, minuciosamente. 
Já no artigo Focale (antigo cachez-nez) eu o disse, e ficará para sempre entendido, que todas as vezes que em português não tivermos termo para exprimir alguma coisa que em língua especial, recorramos ao grego, ou ao latim, formando um neologismo; ou com os elementos do nosso próprio idioma crêemos um novo vocabulário em condições convinháveis.

O vocábulo latino charta (papel), reunido ao vocábulo daps, dapis (comida, iguaria, manjar), pode produzir e produz, com as modificações que a eufonia requer, um termo muito mais expressivo do que o Menu francês.

Diga-se, portanto, Chardapio (cardapio), isto é, papel, lista das comidas, das viandas. N'esta palavra, formada pela íntima soldadura das duas latinas (Charta, e daps, dapis), estão perfeitíssimamente contidas todas as ideias, que de um modo elítico buscaram os franceses exprimir com o seu vocábulo Menu.

No intuito de mais depressa atrair a simpatia para esse neologismo, lembrarei que os franceses chamam também a essa lista Carte, cuja origem latina é charta.

"Garçon, donnez moi la carte", ouve-se a cada passo dizer tanto o francês, como o brasileiro, o português, ou qualquer outro estrangeiro. Em conclusão: não se peça mais ao moço o Menu, nem a Carte; mas o Chardapio (cardápio), que é por todos os motivos preferível ao Menu. (LOPES, 1909: p. 31)

Artur Azevedo ao escrever $O$ Badejo², comédia em 3 atos, em versos, representada pela primeira vez em 15 de outubro de 1898 no Teatro São Pedro de Alcântara, registrou no diálogo de seus personagens essa aversão aos estrangeirismos ao gosto de Castro Lopes:

Angelica

O Cozinheiro

Ramos

O Cozinheiro

Ramos

O Cozinheiro

Ramos

O Cozinheiro

Ramos
Quer saber teu amo o que arranjaste para o almı Fala.

Não pode ser melhor o meu cardápio. Cardápio? Não conheço essa palavra!

Foi arranjada pelo Castro Lopes. Eu não digo mı que é francesismo.

Temos um cozinheiro literato!

Literato não sou, mas sou purista. Embirro com palavras estrangeiras. Hoje, que tudo se naciona nacionalize-se a cozinha!

Bravo! Você é um artista!

$\mathrm{Eu}, \mathrm{um}$ artista?

Sim, um artista da culinária, e a arte não tem pá

Porém, vamos... diga lá o que temos para o almı

\footnotetext{
${ }^{2}$ Disponível em http://www.literaturabrasileira.ufsc.br/_documents/0006-00786.html. Acessado em 28/8/2016.
} 
O Cozinheiro Em primeiro lugar os acepipes. Hors-d'oeuvres direi nem que me rachem!

Menu ou cardápio, o fato é que a mais antiga fonte encontrada, dessa natureza, faz parte do acervo do Instituto Histórico e Geográfico Brasileiro. Trata-se do jantar servido a 120 pessoas no dia 01 de agosto de 1858, oferecido pela Câmara dos Deputados aos membros do Senado, no Clube Fluminense, endereço dos mais concorridos e frequentados pela aristocracia carioca no Império.

No belíssimo menu não há qualquer menção ao anfitrião ou ao homenageado do banquete. Contudo, também nos Arquivos deste Instituto está o fac-símile do Convite da Câmara dos Deputados ao Senado, para o jantar realizado em $1^{o}$ de agosto de 1858. Nele, o Senador Nabuco de Araújo manifesta expressamente aceitar o convite. Foi através desse documento e, da nota publicada sobre o jantar na página 3 da edição 169 do jornal Correio da Tarde, de 2 de agosto de 1858, que identificamos a motivação do refinadíssimo jantar.

Escrito em francês, inteiramente impresso em diferentes tipologias e trazendo detalhes em dourado, o documento chama a atenção pela quantidade e variedade de pratos servidos - 4 sopas, 32 aperitivos, 12 entradas, 4 assados e 12 entremeios. Não bastasse, havia muitas sobremesas: três grandes pâtisseries ornamentais montadas representando o Palácio Imperial, o Palácio do Senado e a Câmara dos Deputados, 16 cestas de frutas, 20 compotas e frutas finas da Europa, 8 bandejas com doces finos, 8 açucareiros ornamentais com frutas cristalizadas, 48 pratos para bolo com fios de ovos e petits-fours variados e, ainda, 8 pratos de queijos, entre os quais figurava o tão genuinamente brasileiro "Fromage de Minas".

Sobre esse valioso menu, o mais antigo de que se tem conhecimento - e uma centena de outros que compõem a coleção do Instituto Histórico e Geográfico Brasileiro -, há certamente muitos aspectos a investigar. Compõem um conjunto de impressos efêmeros que, por excelência, nos permite compreender a História, a Política e a Sociabilidade no Brasil em momentos decisivos do Império à República.

Esperamos que o presente texto tenha sido, ao menos, um modesto aperitivo. Afinal, a qualidade do acervo não nos deixa dúvidas de que, os resultados dessa pesquisa, futuramente, podem ser tão saborosos quanto o melhor dos banquetes.

Bon Appétit! 


\section{Fontes e Bibliografia:}

BASTOS TIGRE, Manoel. Reminiscências. A alegre roda da Colombo e algumas figuras do tempo de antigamente. Brasília: Thesauros, 1992.

BOCCATO, André e LELLIS, Francisco. Os banquetes do Imperador: menus colecionados por D. Pedro II. Receitas e historiografia da gastronomia no Brasil do século XIX. São Paulo: SENAC Editora. São Paulo: Boccato Editora, 2013.

BROCA, Brito. A vida literária no Brasil. Rio de Janeiro: José Olympio/Academia Brasileira de Letras, 2004.

CARDOSO, Rafael (org.). Impresso no Brasil (1808-1930). Destaques da história gráfica no acervo da Biblioteca Nacional. Rio de Janeiro: Verso Brasil Editora, 2009.

- "Os impressos efêmeros como fonte para o estudo da história cultural brasileira”. In: HEYNEMAMM, Cláudia (et all). Marcas do Progresso: consumo e design no Brasil do século XIX. Rio de Janeiro: Mauad X: Arquivo Nacional, 2009, pp. 11 e 12.

Correio da Tarde. Rio de Janeiro. Edição 169 de 02 de agosto de 1858, p. 3.

DÓREA, Eduardo. Histórias de Salvador nos nomes das suas ruas. Bahia: EDUFBA, 2009.

EDMUNDO, Luiz. O Rio de Janeiro do meu tempo. Rio de Janeiro: Conquista, 1957. 5 volumes.

FEBVRE, Lucien Combats pour l'histoire. Paris: Armand Colin, 1953. Apud Jean François Revel. Um banquete de palavras. Uma história da sensibilidade gastronômica. São Paulo: Companhia das Letras, 1996. P. 9.

GARCIA, Lúcia. Para uma História da Belle Époque: a coleção de cardápios de Olavo Bilac. Rio de Janeiro/São Paulo: Academia Brasileira de Letras e Imprensa Oficial do Estado de São Paulo, 2011.

Gazeta de Notícias. Bahia, Salvador, edição 202, ano III, de 14 de maio de 1858, p. 3 . 
GINZBURG, Carlo. Mitos, Emblemas, Sinais. Morfologia e História. São Paulo: Companhia das Letras, 2003.

HEYNEMAMM, Cláudia (et all). Marcas do Progresso: consumo e design no Brasil do século XIX. Rio de Janeiro: Mauad X:Arquivo Nacional, 2009.

LOPES, Antônio de Castro. Neologismos indispensáveis. S/l. S/e. 1909.

NEEDELL, Jeffrey D. Belle Époque tropical - Sociedade e cultura de elite no Rio de Janeiro na virada do século. São Paulo: Companhia das Letras, 1993.

NEVES, Guilherme Pereira das. "História: A polissemia de uma palavra". In: Estudos Ibero-americanos. Porto Alegre, v. 10 nº 1, julho de 1984, p. 17-39.

OTÁVIO, Rodrigo. Minhas Memórias dos Outros. Rio de Janeiro: José Olympio, 1934. 3 volumes.

RENAULT, Delso. A Vida Brasileira no Final do Século XIX. Visão Sócio-Cultural e Política de 1890 a 1901. Rio de Janeiro: José Olympio / INL, 1987.

REVEL, Jean-François. Um banquete de palavras. Uma história da sensibilidade gastronômica. São Paulo: Companhia das Letras, 1996.

RIOS FILHO, Adolfo Morales de los. O Rio de Janeiro Imperial. Rio de Janeiro: Topbooks, $2^{\mathrm{a}}$ edição, 2000.

SODRÉ, Nelson Werneck. A História da Imprensa no Brasil. Rio de Janeiro: Civilização Brasileira, 1966.

STRONG, Roy. Banquete. Uma história ilustrada de culinária, dos costumes e da fartura à mesa. Rio de Janeiro: Jorge Zahar Editor, 2004.

WÄTZOLD, Tim. Proclamação da cozinha brasileira como parte do processo de formação da identidade nacional no Império Brasileiro (1822-1889). Belo Horizonte: Editora TCS, 2012. 
Lúcia Garcia: Pós-doutora, Doutora e Mestre em História pela Universidade do Estado do Rio de Janeiro, mesma universidade onde se graduou, é Professora Adjunta em Ensino de História do Departamento de Estudos Aplicados ao Ensino da Faculdade de Educação da Universidade do Estado do Rio de Janeiro. Foi professora substituta do Departamento de História da Universidade do Estado do Rio de Janeiro, na área de Ensino de História (2013). Possui larga experiência em pesquisa documental e iconográfica e, ao longo de sua trajetória acadêmica, especializou-se nos estudos sobre o período joanino, a História do meio gráfico, dos impressos e dos intelectuais do Império brasileiro. Dedica-se também aos temas relacionados à Educação, História da Educação, Ensino da História e Metodologia de Pesquisa. É autora, entre outros, dos seguintes livros: "Para uma história da Belle Époque: a coleção de cardápios de Olavo Bilac" (Finalista do Prêmio Jabuti, 2012, Categoria Ciências Sociais. O livro traz prefácio de Alberto da Costa e Silva e foi editado pela Academia Brasileira de Letras em coedição com a Imprensa Oficial do Estado de São Paulo, 2011); "Euclides da Cunha: escritor por acidente e repórter do sertão" (São Paulo: Companhia das Letras/ Claroenigma, 2009). Atualmente, também para fins acadêmicos e editoriais, desenvolve pesquisa sobre a coleção de cardápios do Instituto Histórico e Geográfico Brasileiro.

Artigo recebido para publicação em: agosto de 2016 Artigo aprovado para publicação em: setembro de 2016

\section{Como citar:}

GARCIA, Lúcia. A Coleção de Cardápios do Instituto Histórico e Geográfico Brasileiro: Impressos efêmeros como fontes para os estudos sobre História, Política e Sociabilidade. Revista Transversos. "Dossiê: História Pública: Escritas Contemporâneas de História”. Rio de Janeiro, Vol. 07, nº. 07, pp. 185-202, Ano 03. $\quad$ set. 2016. Disponível em: <http://www.e- 
publicacoes.uerj.br/index.php/transversos $>$.

ISSN

$2179-7528$.

DOI:

10.12957/transversos.2016.25307.

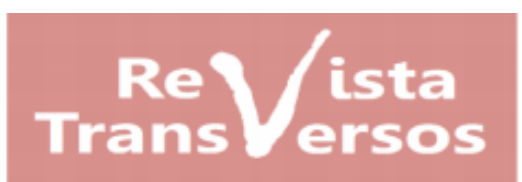

